\title{
The role of sodium chloride on surface properties of chalcopyrite leached with ferric sulphate
}

\author{
M.F.C. Carneiro, V.A. Leão * \\ Núcleo de Valorização de Materiais Minerais, Department of Metallurgical and Materials Engineering, Universidade Federal de Ouro Preto, \\ Praça Tiradentes, 20, Centro, Ouro Preto, MG, 35400-000, Brazil
}

Received 5 January 2006; received in revised form 13 November 2006; accepted 31 January 2007

Available online 14 March 2007

\begin{abstract}
Leaching of chalcopyrite in oxidizing conditions usually results in low copper extraction due to mineral passivation. It has been proposed that sodium chloride has a positive effect on chalcopyrite dissolution increasing copper extraction. Aiming to bring further insight into this topic, the present work seeks to evaluate the influence of sodium chloride on the leaching of chalcopyrite focusing on surface area and porosity of the reaction products formed during leaching. A finely ground $\left(d_{50}=5.5 \mu \mathrm{m}\right)$ chalcopyrite concentrate assaying $25.2 \%$ iron, $30.9 \%$ sulphur and $27.5 \%$ copper was leached in oxygenated ferric sulphate solutions at atmospheric pressure and $95{ }^{\circ} \mathrm{C}$. It has been observed that although sodium chloride favoured natrojarosite precipitation, which reduced the total iron concentration during leaching, copper extractions as high as $91 \%$ were accomplished as compared to $45 \%$ copper extraction in the absence of $\mathrm{NaCl}$. It is suggested that sodium chloride reduces chalcopyrite passivation and complexes $\mathrm{Cu}$ (I) ions adding a second redox couple to the system. Furthermore, morphologic characterization of the reaction products performed by SEM analyses as well as specific surface area and porosity measurements have confirmed that $\mathrm{NaCl}$ increases surface area and porosity of the product layer, which explains the high copper extractions observed in the presence of the salt.

(C) 2007 Elsevier B.V. All rights reserved.
\end{abstract}

Keywords: Chalcopyrite; Leaching; Sodium chloride; Surface area; Porosity

\section{Introduction}

Chalcopyrite accounts for the largest worldwide copper concentrate production and pyrometallurgy is the main route to produce copper from these concentrates (Gupta and Mukherjee, 1990). Conversely, the mineral is mostly refractory to hydrometallurgical processes due to its high chemical stability in aqueous systems (Haver and Wong, 1971).

As far as hydrometallurgy is concerned, leaching is the key step. Copper leaching from chalcopyrite was exten-

\footnotetext{
* Corresponding author. Tel.: +55 313559 1102; fax: +55 3135591561.

E-mail address: versiane@demet.em.ufop.br (V.A. Leão).
}

sively studied in 1970s (Haver and Wong, 1971; Jones and Peters, 1976; Munoz et al., 1979; Yamakawa and Hine, 1970) and the proposed processes had been proven to be technically feasible although not economically viable (Peacey et al., 2005). Currently, both the increase of base metal prices and the stricter environmental regulations have led to a renewed interest in copper hydrometallurgy. As a result, a host of new innovative copper hydrometallurgical processes has been proposed and piloted. These processes have been extensively reviewed (Peacey et al., 2005) and they can be grouped as follows: (i) sulphate processes; (ii) sulphate/chloride processes; (iii) chloride (and bromide) processes. Among these processes, those that rely on ferric sulphate solutions 
present some advantages: the chemical reactions are well understood and copper recovery by solvent extractionelectrowinning is simple (Hackl et al., 1995). The main reaction describing chalcopyrite oxidation by ferric sulphate solutions can be written as:

$\mathrm{CuFeS}_{2}+4 \mathrm{Fe}^{3+} \rightarrow \mathrm{Cu}^{2+} 5 \mathrm{Fe}^{2+} 2 \mathrm{~S}$

It is well known that reaction 1 has a slow kinetics and its rate reduces with time. This is ascribed to the formation of a passivating layer during leaching in oxidizing conditions, which inhibits further reaction (Dreisinger, 2004; Jones and Peters, 1976; Warren et al., 1992). Many studies have been undertaken to establish the nature of this passivating layer and the conditions in which it is formed. In a historical perspective, those studies dealing with leaching kinetics suggested that this layer is composed by non-porous sulphur. Later on, electrochemical experiments (polarization curves, cyclic voltammentry, for instance) have proposed that passivation is caused by an amorphous non-stoichiometric sulphide (Warren et al., 1992).

A review of the several processes that use chloride to leach base metals sulphide can be found elsewhere (Dreisinger, 2004; Dutrizac, 1992; Prasad and Pandey, 1988; Venkatachalam, 1991). The interest in chloride systems relies on the high solubility of both copper and ferric iron in these systems as well as the easiness of ferric ion regeneration. In addition, chalcopyrite leaching with ferric chloride shows faster kinetics than ferric sulphate solutions. These studies have also suggested that the sulphur formed as reaction product is more porous when leaching was carried out in the presence of chloride ions. Recently, Lu et al. (2000a,b,c) have studied the effect of chloride ions on the sulphate leaching of different sulphide minerals using oxygenated solutions. They also proposed that a porous sulphur layer (reaction product) was formed in the presence of $\mathrm{NaCl}$, which facilitated the reagent diffusion to the mineral surface. Additionally, Winand (1991) studying chalcopyrite leaching in the presence of chloride ions has attributed higher leaching yields to the formation of copper complex with $\mathrm{Cl}^{-}$which led to a higher copper solubility in $\mathrm{Cl}^{-}-\mathrm{Cu}(\mathrm{II})-\mathrm{Cu}(\mathrm{I})$ systems .

This work sought to provide further insight into the role of chloride ions on the ferric sulphate leaching of chalcopyrite. It will be demonstrated that $\mathrm{NaCl}$ enhances chalcopyrite dissolution by increasing surface area and porosity, changing the morphology of the reaction product. This feature will be discussed in light of the several proposed effects of chloride ions onto chalcopyrite leaching and will lead to a greater understanding of the whole process.

\section{Experimental}

\subsection{Reagents and leaching procedure}

The chalcopyrite concentrate was kindly provided by "Caraíba Metais" a pyrometallurgy facility in Bahia, Brazil. This concentrate contained $69 \%$ chalcopyrite, $27 \%$ pyrite and $4 \%$ of an oxidized copper phase. Chemical analysis showed $25.2 \%$ iron, $30.9 \%$ sulphur and $27.5 \%$ copper. Before leaching, the concentrate was dry ground in a vibrating cup mill (Pulverisette 9, Fritsch) and the final sample had a $d_{50}=5.5 \mu \mathrm{m}$.

The experimental set-up consisted of a conventional leaching apparatus formed by a $500 \mathrm{~mL}$ four-neck borosilicate glass reactor. Stirring was provided by a magnetic stirrer (Ika Ceramag Midi), which also heated the reactor. Additional heating was supplied by a $5 \mathrm{~cm}$ heating tape (Fisatom, model 5 Standard Class 300). Temperature was thermostatically controlled (Fisatom temperature controller) at $95{ }^{\circ} \mathrm{C}$ and the reactor was operated under closed conditions. A $0.5 \mathrm{~m}$ long straight condenser was connected to one neck to enable gases to escape and to reduce evaporation losses as oxygen (99\%) was bubbled during the whole experiment. Unless otherwise stated, its flowrate was controlled (Omega rotameter) at $0.45 \mathrm{~L} / \mathrm{min} \mathrm{O}_{2}$.

The leaching solutions were prepared by mixing ferric sulphate $\left(\mathrm{Fe}_{2}\left(\mathrm{SO}_{4}\right)_{3} \cdot 5 \mathrm{H}_{2} \mathrm{O}\right.$, Synth) and sodium chloride ( $\mathrm{NaCl}$, Synth). This solution was transferred to the reactor and $\mathrm{pH}$ was adjusted to 0.15 with concentrated $\mathrm{H}_{2} \mathrm{SO}_{4}$. Next, oxygen bubbling was started and the leaching solution was stirred and heated until it reached the desired temperature. Then, chalcopyrite concentrated was added to the system to produce a $5.0 \%(\mathrm{w} / \mathrm{v})$ pulp. Samples of the solution were withdrawn at predetermined time intervals. At the end of the experiment, the pulp was filtered and the residue was washed with distilled water.

Copper and $\mathrm{Fe}_{\mathrm{T}}$ (total iron) were assayed by atomic absorption spectroscopy (AAS) in a Perkin Elmer Aanalyst 100 device. $\mathrm{Fe}$ (II) was determined by titration with a standardized potassium dichromate solution $\left(\mathrm{K}_{2} \mathrm{Cr}_{2} \mathrm{O}_{7}\right)$ in the presence of an 1:1 ratio of $\mathrm{H}_{2} \mathrm{SO}_{4} / \mathrm{H}_{3} \mathrm{PO}_{4}(\mathrm{v} / \mathrm{v})$ solution using an automatic titrator (Tritoline Alpha, Schott).

\subsection{Surface analysis}

For the morphological studies, the concentrate was leached under a slightly different condition than those described in the leaching experiments. The experiments were performed with: $50 \mathrm{~g} / \mathrm{L} \mathrm{Fe}(\mathrm{III})\left(\right.$ as $\left.\mathrm{Fe}_{2}\left(\mathrm{SO}_{4}\right)_{3}\right) ; 0$ or $1.0 \mathrm{~mol} / \mathrm{L} \mathrm{NaCl} ; 5.0 \%$ (w/v) solids; oxygen flowrate $0.45 \mathrm{~L} / \mathrm{min} ; 95^{\circ} \mathrm{C}$. The $\mathrm{pH}$ was set to 0.0 to reduce 
jarosite precipitation on the leaching residue. After $4 \mathrm{~h}$ leaching time, the solids were filtered, washed with distilled water and dried at $55{ }^{\circ} \mathrm{C}$, for $24 \mathrm{~h}$.

Surface area and pore volume were determined by nitrogen adsorption. Nitrogen isotherms were performed with a Nova 1000 High Speed Gas Sorption Analyzer (Quantachrome). Sample degassing was carried out at ambient temperature for $24 \mathrm{~h}$ to avoid (or minimize) effects of high temperature degassing on the sulphur layer formed during leaching. Nitrogen adsorption was performed at $-196{ }^{\circ} \mathrm{C}$. Data were collected from a relative pressure $\left(p / p_{0}\right)$ of 0.05 to 0.98 .

Total surface area was calculated using the Brunauer Emmett Teller (BET) adsorption isotherm model (Rouquerol and Sing, 1999) for the nitrogen isotherm data. Surface area was calculated from the slope and $y$ intercept of the linear region of the BET transformation versus relative pressure plots. The nitrogen adsorptiondesorption data were also used to calculate the total micro-pore volume and micro-pore surface area using the Dubinin-Radushkevich (DR) potential theory. The micro-pore volume was calculated as the $y$-intercept of a plot of the adsorption data in the following equation (Rouquerol and Sing, 1999):

$\log V=\log V_{0}-D \log \left(p / p_{0}\right)^{2}$

where $V$ and $V_{0}$ are the volume of nitrogen adsorbed and micro-pore volume, respectively, $p / p_{0}$ the relative pressure, and $D$ is a constant related to the energy of adsorption. Surface area and porosity results were obtained from at least three determinations for 95\% confidence interval (Filfield and Kealey, 1995).

\subsection{Scanning electron microscopy}

Scanning electron microscopy (SEM) was used to examine the morphology of the leach residues. The samples were coated with graphite by electro-deposition, using a Jeol JEE 4C instrument and investigated by a JEOL JSM 5510 scanning electron microscope (SEM), with an accelerating voltage $0.5-30 \mathrm{kV}$ and equipped with a spectrometer for micro-analysis based on an energy dispersive X-ray spectroscopy system (EDS).

\section{Results}

\subsection{Influence of sodium chloride concentration on chemical leaching}

The leaching of the chalcopyrite concentrate was initially studied by using solutions containing $50 \mathrm{~g} / \mathrm{L} \mathrm{Fe}$ (III) (as ferric sulphate) and different sodium chloride concentrations, at $95{ }^{\circ} \mathrm{C}$. Fig. 1 shows the percentage of copper leached from the concentrate. When chloride ions are absent, it can be seen that the leaching is very slow, with only $45 \%$ of the copper being extracted in a period of $10 \mathrm{~h}$. This result is consistent with the slow kinetics observed in other studies of chalcopyrite leaching on sulphate systems (Hackl et al., 1995; Hirato et al., 1986; Jones and Peters, 1976; Majima et al., 1985; Munoz et al., 1979). According to these previous works the low copper extraction can be credited to the passivation of chalcopyrite surface. Fig. 1 also shows that at $0.5 \mathrm{~mol} / \mathrm{L} \mathrm{Cl}^{-}$, copper dissolution increases to $55 \%$. Much better extractions are observed for higher $\mathrm{NaCl}$ concentrations as copper dissolution reaches a maximum slightly above $90 \%$, at $1.0-2.0 \mathrm{~mol} / \mathrm{L} \mathrm{NaCl}$. These results confirm the positive effect of the presence of chloride ions on chalcopyrite leaching (Carneiro and Leão, 2005; Hirato et al., 1986; Majima et al., 1985; Skorobian et al., 2005). Under similar conditions to those of the present work, Carneiro and Leão (2005) have shown that the presence of sodium chloride also increased chalcopyrite leaching with ferric chloride. However, the effect was less pronounced: copper extraction increased from $70 \%$ (without $\mathrm{NaCl}$ ) to $81 \%$ $(1 \mathrm{~mol} / \mathrm{L} \mathrm{NaCl})$. As in the present work copper dissolution increased from $45 \%$ (no $\mathrm{NaCl}$ ) to $91 \%(1 \mathrm{~mol} / \mathrm{L} \mathrm{NaCl})$, chloride addition has a more important role on leaching with $\mathrm{Fe}_{2}\left(\mathrm{SO}_{4}\right)_{3}$ than $\mathrm{FeCl}_{3}$.

Total iron and $\mathrm{Fe}(\mathrm{II})$ concentrations are depicted in Figs. 2 and 3, respectively. Both figures show that the total iron content is lower and $\mathrm{Fe}(\mathrm{II})$ concentrations are higher in the presence of $\mathrm{NaCl}$. In those experiments where $\mathrm{NaCl}$ is added, $\mathrm{Na}^{+}$ions led to the precipitation of natrojarosite (reaction 3 and Fig. 4) reducing the Fe(III) concentration during the experiments. Natrojarosite is not observed in the experiments performed without $\mathrm{NaCl}$. Interestingly, the observed higher $\mathrm{Fe}(\mathrm{III})$

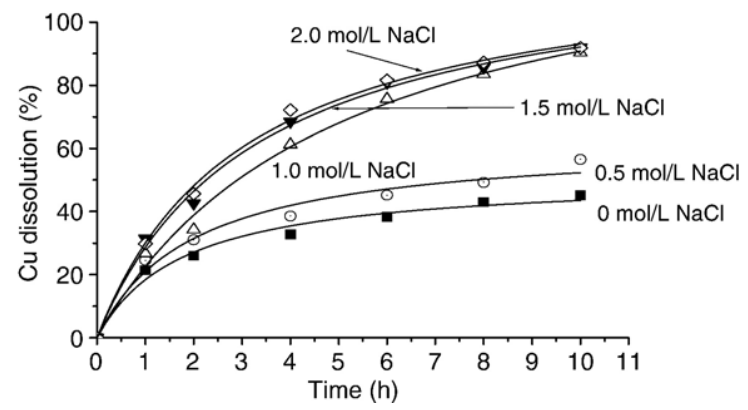

Fig. 1. Effect of $\mathrm{NaCl}$ concentration on copper extraction during ferric sulphate leaching of chalcopyrite. Experimental conditions: $d_{50}$ : $5.5 \mu \mathrm{m} ; 50 \mathrm{~g} / \mathrm{L} \mathrm{Fe}^{3+} ; \mathrm{pH} 0.15$ (initial); $0.45 \mathrm{~L} / \mathrm{min} \mathrm{O}_{2} ; 5.0 \%$ solids (w/v); temperature: $95^{\circ} \mathrm{C}$. 


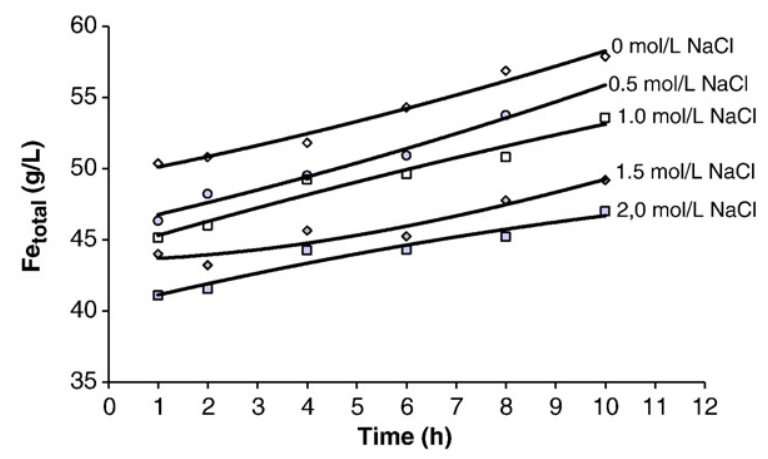

Fig. 2. Total iron concentration as a function of time for chalcopyrite leaching with ferric sulphate in the presence of $\mathrm{NaCl}$. Experimental conditions: $d_{50}: 5.5 \mu \mathrm{m} ; 50 \mathrm{~g} / \mathrm{L} \mathrm{Fe}^{3+} ; \mathrm{pH} 0.15$ (initial); $0.45 \mathrm{~L} / \mathrm{min} \mathrm{O}_{2}$; $5.0 \%$ solids $(\mathrm{w} / \mathrm{v})$; temperature: $95^{\circ} \mathrm{C}$.

concentration in the absence of sodium chloride does not result in a faster or higher copper extraction, suggesting that other effects are responsible for the low recoveries.

$$
\begin{aligned}
& 3 \mathrm{Fe}^{3+}+2 \mathrm{SO}_{4}^{2-}+6 \mathrm{H}_{2} \mathrm{O} \\
& \quad+\mathrm{Na}^{+} \rightarrow \mathrm{Na}\left[\mathrm{Fe}(\mathrm{OH})_{2}\right]_{3}\left(\mathrm{SO}_{4}\right)_{2}+6 \mathrm{H}^{+}
\end{aligned}
$$

Lu et al. (2000a) have also observed that the presence of sodium chloride during leaching caused natrojarosite precipitation. In their study $\mathrm{Fe}(\mathrm{III})$ was not added and the oxidative conditions were provided only by oxygen bubbling. Thus, the precipitated Fe(III) was originated from the chalcopyrite concentrate itself.

As shown in Fig. 1, the copper extraction reached $75 \%$ in $6 \mathrm{~h}$ and $91 \%$ in $10 \mathrm{~h}$. These high yields can also be credited to the small particle size of the chalcopyrite sample $\left(d_{50}=5.5 \mu \mathrm{m}, d_{100}=50 \mu \mathrm{m}\right)$ which is consistent with the work of Maurice and Hawk (1998) that observed $70 \%$ copper extraction for a $-37 \mu \mathrm{m}$ particle size concentrate leached with $1.0 \mathrm{~mol} / \mathrm{L} \mathrm{FeCl}_{3}$ and $1.0 \mathrm{~mol} / \mathrm{L} \mathrm{NaCl}\left(1.0 \%\right.$ solids, $\left.90{ }^{\circ} \mathrm{C}\right)$, in $5 \mathrm{~h}$. High extractions were also observed by $\mathrm{Lu}$ et al. (2000a) in which $97 \%$ copper dissolution was achieved during ferric sulphate leaching of a coarser chalcopyrite concentrate $\left(d_{50}=15.1 \mu \mathrm{m}, d_{100}=180 \mu \mathrm{m}\right)$ in the presence $0.5 \mathrm{~mol} / \mathrm{L} \mathrm{NaCl}$ and $95{ }^{\circ} \mathrm{C}(9 \mathrm{~h}$ leaching time). Such high copper dissolutions during leaching of coarse concentrates are however not expected. For instance, only $35 \%$ copper dissolution (in $6 \mathrm{~h}$, at $90{ }^{\circ} \mathrm{C}$ ) was observed during chalcopyrite leaching with $1.0 \mathrm{~mol} / \mathrm{L} \mathrm{FeCl}_{3}$ (and $\mathrm{CCl}_{4}$ ) of a $-100 \mu \mathrm{m}$ concentrate (Havlik and Kammel, 1995). In addition, Dreisinger (2004), discussing the effect of particle size on the pressure leaching (in the absence of chloride) of chalcopyrite $\left(150{ }^{\circ} \mathrm{C}\right)$, stated that higher than $90 \%$ extraction is only achieved for particle size below $13 \mu \mathrm{m}$. According to the author, copper extraction sharply reduced to $80 \%$ when particle size increased to $18 \mu \mathrm{m}$. These different studies suggest therefore that fast chalcopyrite leaching of coarse concentrate such as that observed by Lu et al. (2000a) is likely associated to the nature of the chalcopyrite sample.

\subsection{Morphology and surface parameters of the leach residues}

Surface area and porosity were determined aiming to gain insight on the effect of the presence of chloride ions on surface properties of the ferric sulphate leaching residue. Table 1 summarizes the results achieved for the concentrate and the residue generated both in the presence and in the absence of sodium chloride. Surface area of the concentrate measured $1.51 \pm 0.23 \mathrm{~m}^{2} / \mathrm{g}$. This value is within the range observed in studies of fine grinding of chalcopyrite samples, which ranges from 0.5 to $5.0 \mathrm{~m}^{2} / \mathrm{g}$ (Amer, 1995; Baláz et al., 1996; Maurice and Hawk, 1998).

It can be noticed that residue's surface area and porosity (both volume and area) are higher in the presence of sodium chloride, which can be directly related to the higher extraction observed in the presence of $\mathrm{NaCl}$. Higher porosity facilitates diffusion of reagent and products to and from the reaction sites. Carneiro and Leão (2005) have also observed a beneficial effect of sodium chloride on surface properties of chalcopyrite residues leached with $\mathrm{FeCl}_{3}$, but the effect was less pronounced. Surface area and micro-pores area slightly increased from $0.71 \pm 0.05 \mathrm{~m}^{2} / \mathrm{g}$ and $0.87 \pm 0.06 \mathrm{~m}^{2} / \mathrm{g}$, to $0.94 \pm 0.13 \mathrm{~m}^{2} / \mathrm{g}$ and $1.10 \pm 0.15 \mathrm{~m}^{2} / \mathrm{g}$, respectively, in the absence and presence of $\mathrm{Cl}^{-}(1 \mathrm{~mol} / \mathrm{L})$.

SEM observations of the concentrate and leach residues indicate different morphologies (Fig. 5). One chalcopyrite particle is depicted in Fig. 5(a). After $4 \mathrm{~h}$ of

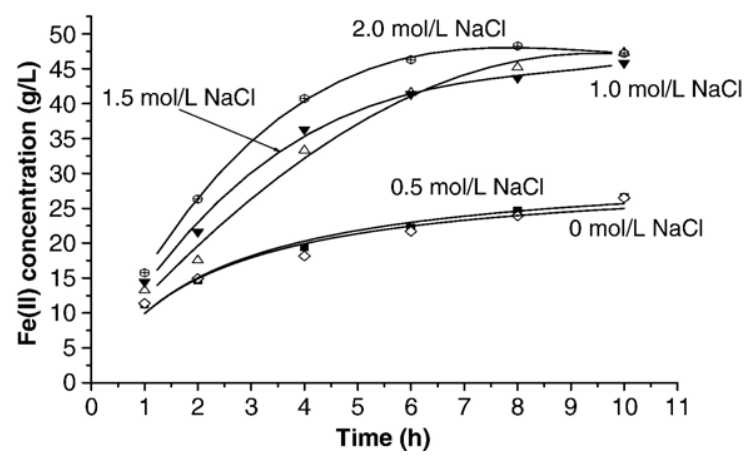

Fig. 3. Time dependence of $\mathrm{Fe}(\mathrm{II})$ concentration for chalcopyrite leaching with ferric sulphate in the presence of $\mathrm{NaCl}$. Experimental conditions: $d_{50}: 5.5 \mu \mathrm{m} ; 50 \mathrm{~g} / \mathrm{L} \mathrm{Fe}^{3+} ; \mathrm{pH} 0.15$ (initial); $0.45 \mathrm{~L} / \mathrm{min} \mathrm{O}_{2}$; $5.0 \%$ solids $(\mathrm{w} / \mathrm{v})$; temperature: $95{ }^{\circ} \mathrm{C}$. 


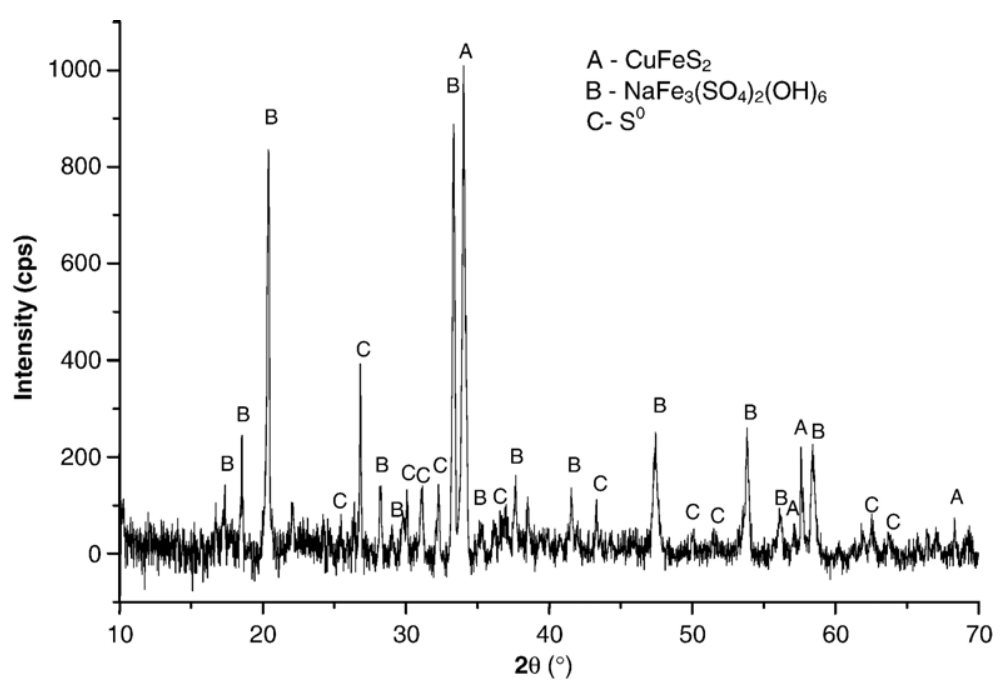

Fig. 4. X-ray diffraction of the residue produced during chalcopyrite leaching with ferric sulphate and sodium chloride. Experimental conditions: $d_{50}$ : $5.5 \mu \mathrm{m} ; 50 \mathrm{~g} / \mathrm{L} \mathrm{Fe}^{3+} ; 1 \mathrm{~mol} / \mathrm{L} \mathrm{NaCl} ; \mathrm{pH} 0.15$ (initial); $0.45 \mathrm{~L} / \mathrm{min} \mathrm{O}_{2} ; 5.0 \%$ solids (w/v); temperature: $95{ }^{\circ} \mathrm{C} ; 10 \mathrm{~h} \mathrm{leaching}$ time.

leaching, a lamellar film is noticed covering the residue produced in the absence of chloride ions (Fig. 5(b) and (c)). It seems that the reaction product has grown following the morphology of the chalcopyrite particle which is consistent with the observations of Majima et al. (1985). Nevertheless, in the presence of $\mathrm{NaCl}$ the elemental sulphur morphology is different (Fig. 5(d) and (e)). A more dense structure is formed and grows in preferential directions suggesting some crystalline structure. Lu et al. (2000a,b,c) proposed that the reaction product is elemental sulphur in both cases. In the present work, X-ray diffraction showed the presence of elemental sulphur in the residue (Fig. 4) although it was not seen by SEM-EDS on the chalcopyrite surface. EDS always showed a phase formed by sulphur, copper and iron, where the sulphur content was higher than in the concentrate. As EDS and X-ray diffraction did not confirm the presence of jarosite as the reaction product, it is suggested that the main reaction product was elemental sulphur.

The positive effects of chloride ions on chalcopyrite leaching enabled the development of a series of processes to leach chalcopyrite with chloride ions $\left(\mathrm{FeCl}_{2}, \mathrm{CuCl}_{2}\right)$. These processes are far more common than those based on the chloride/sulphate route. The former include the CLEAR, CUPREX, CYMET, Minemet, and Outokumpu, among other processes. All of them can be represented, essentially, by the following set of equations:

$$
\begin{aligned}
& \mathrm{CuFeS}_{2} \rightarrow \mathrm{Cu}^{+}+\mathrm{Fe}^{2+}+2 \mathrm{~S}^{0}+3 \mathrm{e} \\
& \mathrm{Cu}^{+}+n \mathrm{Cl}^{-}=\left[\mathrm{CuCl}_{n}\right]^{1-n}
\end{aligned}
$$

There is, however, an important difference as compared to ferric sulphate leaching. As cuprous ions are stable in chloride systems, the $\mathrm{Cu}(\mathrm{II}) / \mathrm{Cu}(\mathrm{I})$ couple (instead of $\mathrm{Fe}(\mathrm{III}) / \mathrm{Fe}(\mathrm{II})$ ) becomes the main chalcopyrite oxidant provided enough chloride is available:

$\mathrm{CuFeS}_{2}+3 \mathrm{Cu}^{2+}=4 \mathrm{Cu}^{+}+\mathrm{Fe}^{2+}+2 \mathrm{~S}$

These processes were carried out at low pressure and therefore fine milled concentrates and leaching near the solution boiling point were required for higher than $95 \%$

Table 1

Surface parameters of chalcopyrite concentrate and residues of ferric sulphate leaching with and without sodium chloride

\begin{tabular}{lccc}
\hline Parameter & Chalcopyrite concentrate & $\begin{array}{l}\text { Residue after } \mathrm{Fe}_{2}\left(\mathrm{SO}_{4}\right)_{3} \\
\text { leaching with } \mathrm{NaCl}\end{array}$ & $\begin{array}{l}\mathrm{Residue} \mathrm{after} \mathrm{Fe}_{2}\left(\mathrm{SO}_{4}\right)_{3} \\
\text { leaching without NaCl}\end{array}$ \\
\hline Surface area $\left(\mathrm{m}^{2} / \mathrm{g}\right)$ & $1.51 \pm 0.23$ & $1.41 \pm 0.01$ & $1.00 \pm 0.04$ \\
Microporous volume $\left(\mathrm{cm}^{3} / \mathrm{g}\right)$ & $(6.60 \pm 0.84) \times 10^{-4}$ & $(6.28 \pm 0.05) \times 10^{-4}$ & $(4.48 \pm 0.06) \times 10^{-4}$ \\
Microporous area $\left(\mathrm{m}^{2} / \mathrm{g}\right)$ & $1.86 \pm 0.23$ & $1.78 \pm 0.01$ & $1.27 \pm 0.02$ \\
\hline
\end{tabular}

Leach residues produced under the following experimental conditions: $d_{50}: 5.5 \mu \mathrm{m} ; \mathrm{pH}: 0.0$ (initial); $50 \mathrm{~g} / \mathrm{L} \mathrm{Fe}^{3+} ; 0.45 \mathrm{~L} / \mathrm{min} \mathrm{O}_{2} ; 5.0 \%$ solids $(\mathrm{w} / \mathrm{v})$; temperature: $95^{\circ} \mathrm{C}$; time: $4 \mathrm{~h}$. $\mathrm{NaCl}: 1.0 \mathrm{~mol} / \mathrm{L}$. 
(a)

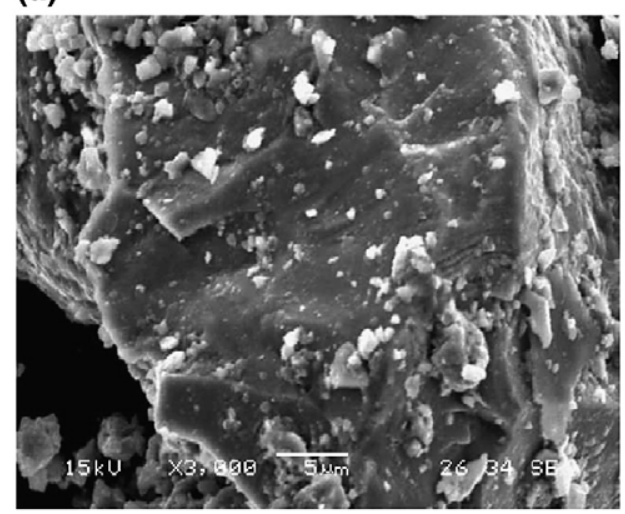

(b)

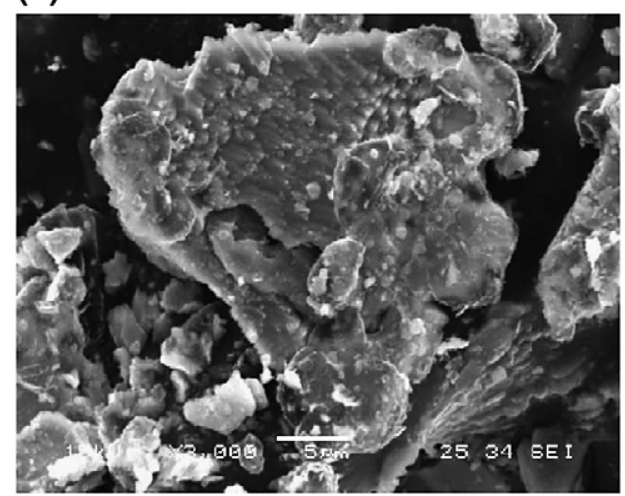

(c)

(d)

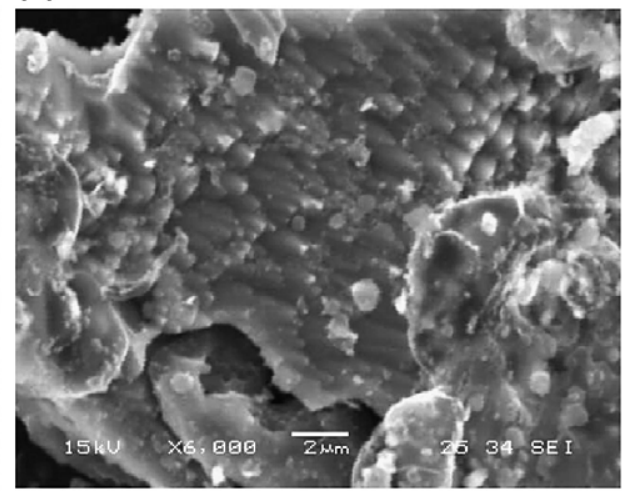

(e)
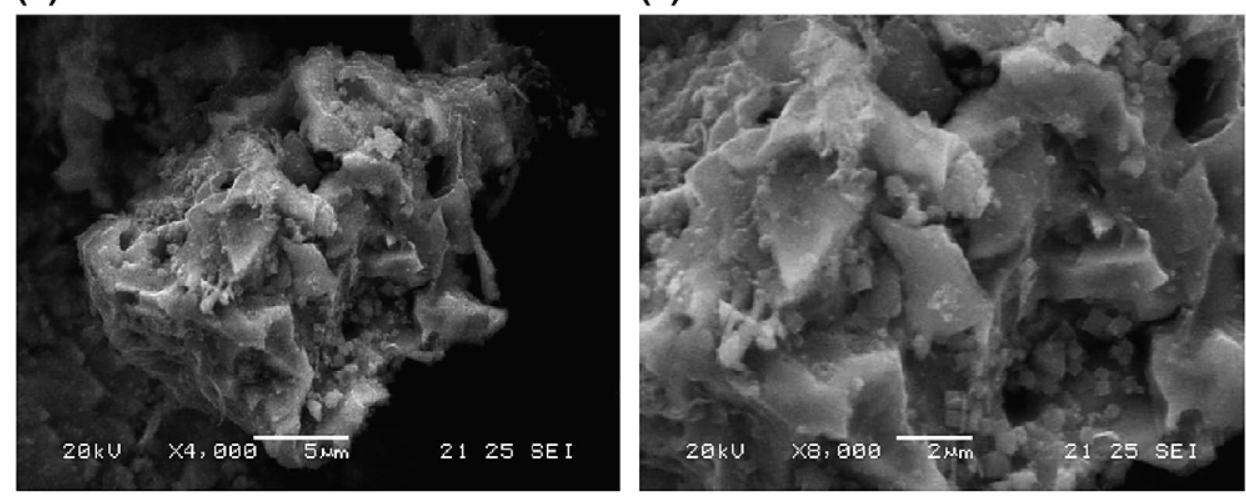

Fig. 5. Secondary electron micrograph of chalcopyrite before leaching. (a) Leach residues produced in the absence of $\mathrm{NaCl}$ : $3000 \times$ (b) and $6000 \times$ (d); leach residues obtained in the presence of $\mathrm{NaCl}: 4000 \times$ (d) and $8000 \times$ (e). Panels (b) and (c) as well as panels (d) and (e) show the same particle, respectively.

copper extractions. Either gaseous oxygen or Fe(III) reoxidised $\mathrm{Cu}$ (I) to $\mathrm{Cu}$ (II) ensuring a high potential during leaching. Copper was recovered by different routes. The CLEAR process added powdered metallic copper to the pregnant solution to reduce all copper to $\mathrm{Cu}(\mathrm{I})$. Then, copper was produced by electrolysis using a diaphragm cell. High current densities were applied and together with mechanical agitation produced coarse copper grains suitable to be melted without significant metal oxidation. The Minemet process extracted copper from the pregnant solution with LIX-65N after oxygen injection to oxidize copper to $\mathrm{Cu}(\mathrm{II})$. After scrubbing the chloride ions, the loaded organic was stripped with sulphuric acid so that a conventional acidic $\mathrm{CuSO}_{4}$ solution was produced and electrowon. The Cuprex process applied a different extractant (ACORGA CLX 
50) to selectively extract cupric chloride. Then, the loaded organic was stripped with water to produce a concentrated $\mathrm{CuCl}_{2}$ solution. This solution was electrolyzed in the presence of cation-selective membrane producing high purity copper powders. Silver recovery is usually a drawback in these processes (with the exception of the Cuprex process), as it was not easily removed from the pregnant solution and followed copper during electrowinning (Dutrizac, 1992). More recently, Outokumpu has proposed a similar process where chalcopyrite leaching is performed at atmospheric pressure with a chlorine-cupric chloride-brine solution. In this process, chlorine oxidizes $\mathrm{Cu}(\mathrm{I})$ to $\mathrm{Cu}$ (II) and copper is recovered from the purified leach solution by precipitating cuprous oxide with caustic soda. Then, metallic copper is produced by hydrogen reduction. Chlorine is regenerated using chloroalkali cell technology (Dreisinger, 2004).

Mixed sulphate/chloride systems are represented by the Noranda process in which chalcopyrite was converted to solid $\mathrm{CuSO}_{4} \cdot \mathrm{Cu}(\mathrm{OH})_{2}$ instead of cupric or cuprous ions, at $135-145^{\circ} \mathrm{C}$ and $1370 \mathrm{KPa}$ oxygen. Hematite and elemental sulphur were also produced. Basic copper sulphate was then leached in a $\mathrm{pH} 2.5$ sulphuric acid solution. Using a similar approach, the CESL process uses pressure oxidation $\left(150^{\circ} \mathrm{C}, 700 \mathrm{KPa}\right.$ $\mathrm{O}_{2}, 1100 \mathrm{KPa}$ total pressure) with chloride $\left(12 \mathrm{~g} / \mathrm{L} \mathrm{Cl}^{-}\right)$ as a catalyst to produce $\mathrm{CuSO}_{4} \cdot \mathrm{Cu}(\mathrm{OH})_{2}$ which is leached by sulphuric acid. Gold is recovered from the residue by cyanidation following elemental sulphur removal, so that cyanide consumption is reduced (Defreyne et al., 2004).

\section{Discussion}

The improvement on chalcopyrite leaching by chloride ions was soon recognized. As early as 1970s, researches on chalcopyrite leaching had highlighted that ferric chloride gives faster leaching kinetics than ferric sulphate (Gupta and Mukherjee, 1990; Jones and Peters, 1976). This improvement is credited, at least, to the following reasons: (i) formation of copper chloride complexes; (ii) increase in the anodic current during chalcopyrite leaching, (iii) changes on the surface form and properties of the reaction product. These aspects will be discussed in light of the results of the present work.

\subsection{Copper-chloride complexes}

Some authors have attributed the increase in copper leaching from chalcopyrite to the formation of copper- chloride complexes. Chloride can complex and stabilize $\mathrm{Cu}(\mathrm{I})$ ions thereby increasing copper solubility although high $\mathrm{Cl}^{-}$concentrations are required to avoid $\mathrm{CuCl}$ precipitation.

Considering the high ionic concentrations in leaching systems, NIST database shows $4 \mathrm{Cu}(\mathrm{I})-\mathrm{Cl}$ complexes at high ionic strength ( $\mathrm{I}=5.0): \mathrm{CuCl}^{0} \quad\left(\log \beta_{1}=2.7\right)$; $\mathrm{CuCl}_{2}^{-}\left(\log \beta_{2}=6.1\right) ; \mathrm{CuCl}_{3}^{-2}\left(\log \beta_{3}=6.0\right) ; \mathrm{Cu}_{2} \mathrm{Cl}_{4}^{-2}$ $\left(\log \beta_{4}=13.0\right)$. Conversely, only one complex is listed for $\mathrm{Cu}$ (II) with a low stability constant $\left(\mathrm{CuCl}^{+}, \log \right.$ $\left.\beta_{1}=0.17\right)$. $\mathrm{Fe}(\mathrm{III})$ and $\mathrm{Fe}(\mathrm{II})$ also show only one chlorocomplex each: $\mathrm{Fe}(\mathrm{III})-\mathrm{Cl}^{-}$with a higher stability $\left(\mathrm{FeCl}^{+2}, \log \beta_{1}=1.3\right)$; as compared to $\mathrm{Fe}(\mathrm{II}) \mathrm{Cl}^{+}$(log $\beta_{1}=0.2, \mathrm{I}=0$ ); i.e. unlike $\mathrm{Cu}(\mathrm{I})$, cupric copper and iron ions do not show strong chloride complexes (Martell and Smith, 2003).

Despite some controversy, recent studies have suggested that copper is monovalent in the chalcopyrite structure (Boekema et al., 2004; Pearce et al., 2006). A comprehensive discussion of copper and iron oxidation states in chalcopyrite is beyond the scope of the present work, but considering that copper is present in chalcopyrite as $\mathrm{Cu}^{+1}$, it would be complexed by $\mathrm{Cl}^{-}$ during leaching. Therefore, chloride would enhance leaching by increasing copper(I) solubility as $\mathrm{Cu}(\mathrm{I})$ complexes. Notwithstanding, the oxidizing conditions prevailing during leaching in the present work (presence of Fe(III) and oxygen) make this assumption unlikely as the ferric chloride oxidation of cuprous ions (Eq. (7)) is one of the key reactions during ferric chloride leaching of chalcopyrite (Dutrizac, 1992; Winand, 1991).

$\mathrm{Fe}^{3+}+\mathrm{Cu}^{+}=\mathrm{Fe}^{2+}+\mathrm{Cu}^{2+} \quad \Delta E^{0}=0.1 \mathrm{~V}$

In addition, $E_{h}$ measurements have shown potentials in the range $700-425 \mathrm{mV}(\mathrm{Ag} / \mathrm{AgCl})$ during the whole experiment of the present work which is above the rest potential of $\mathrm{Cu}$ (I) oxidation to $\mathrm{Cu}$ (II) $(600 \mathrm{mV}$, versus $\mathrm{SHE}$, at $0.1 \mathrm{~mol} / \mathrm{L} \mathrm{CuCl}_{2}, 0.1 \mathrm{~mol} / \mathrm{L} \mathrm{CuCl}, 0.2 \mathrm{~mol} / \mathrm{L}$ $\mathrm{HCl}, 3.0 \mathrm{~mol} / \mathrm{L} \mathrm{NaCl}$ ) (Hirato et al., 1987). Regarding the kinetics of copper(I) oxidation by $\mathrm{Fe}(\mathrm{III})$ no information could be found, but it has been observed that provided enough $\mathrm{Fe}(\mathrm{III})$ is available, $\mathrm{Cu}$ (II) was the only copper species observed during chalcopyrite leaching with ferric chloride (O'Malley and Liddell, 1987) which suggests that $\mathrm{Cu}(\mathrm{I})$ oxidation by $\mathrm{Fe}(\mathrm{III})$ is fast. Furthermore, copper(I) oxidation on the surface of chalcopyrite in the presence of chloride ions is also fast (Yamakawa and Hine, 1970). Therefore Cu(I) concentrations in oxidizing systems should be low and would not explain the high chalcopyrite dissolution in the presence of chloride ions. Chloride effects are thus 
related to the electrochemistry of leaching and surface properties as will be discussed in the next paragraphs.

\subsection{Electrochemistry of chalcopyrite in the presence of $\mathrm{Cl}^{-}$ions}

The concept that sulphide and oxides are leached by an electrochemical mechanism was proposed by Nicol et al. (1975). Since then an electrochemical approach has been used to study chalcopyrite (and other sulphides) leaching. During chalcopyrite leaching, a parabolic kinetics is observed which is attributed to the passivation of its surface. Electrochemical studies (anodic polarization curves and cyclic voltammetry, among other techniques) enabled the proposition that passivation occurs due to the formation of a surface layer that inhibits dissolution. It is agreed that iron is leached ahead of copper, higher temperature reduces the passivation phenomena and impurities affect the oxidation behaviour of specific samples of chalcopyrite. Furthermore, passivation starts after a certain potential, which depends on the sample studied, usually on the $250-450 \mathrm{mV}(\mathrm{Ag} / \mathrm{AgCl})$ range. Working below this "critical" potential allows the non-oxidative leaching of chalcopyrite (Lazaro and Nicol, 2003).

The accepted reaction describing the formation of this passivating layer is as follows:

$$
\begin{aligned}
& \mathrm{CuFeS}_{2} \rightarrow \mathrm{Cu}_{1-x} \mathrm{Fe}_{1-y} \mathrm{~S}_{2-z}+x \mathrm{Cu}^{+2}+y \mathrm{Fe}^{+2}+z \mathrm{~S} \\
& \quad+2(x+y) \mathrm{e}
\end{aligned}
$$

As shown in Eq. (8), the passivation layer is believed to be formed by $\mathrm{Cu}_{1-x} \mathrm{Fe}_{1-y} \mathrm{~S}_{2-z}$ or something similar (layers of a non-stoichiometric compounds presenting S-S bonds (Mikhlin et al., 2004)). It has also been suggested that this layer is around $20 \mathrm{~nm}$ thick (Lazaro and Nicol, 2003).

It has been shown that chloride ions also affect the electrochemical behaviour of chalcopyrite (passivation). Current-time curves for chalcopyrite oxidation at constant potential show a decrease in the current passing through the working electrode. The initial current reduces with time and reaches a steady value which is consistent with the passivating of the mineral surface. However, in the presence of sodium chloride this steady value of current is higher than in its absence. It has been show that in the presence of $0.5 \mathrm{~mol} / \mathrm{L} \mathrm{NaCl}$ the current density is 7 times higher than in the absence of this salt (Lu et al., 2000b). This increase may be attributed to a change in the leaching mechanism since $\mathrm{Fe}(\mathrm{III}) / \mathrm{Fe}$ (II) is the single redox couple in the absence of $\mathrm{NaCl}$, but the $\mathrm{Cu}(\mathrm{II}) / \mathrm{Cu}(\mathrm{I})$ couple becomes more important in the presence of chloride ions since the latter is more reactive
(Hirato et al., 1987). The evidences of this phenomenon are the increase in the mixed potential during chalcopyrite oxidation with $\mathrm{FeCl}_{3}$ due to the addition of $\mathrm{Cu}$ (II) ions, and the large exchange current density observed during copper(II) reduction (or $\mathrm{Cu}(\mathrm{I})$ oxidation) on chalcopyrite surface (Hirato et al., 1986). Eq. (6) has therefore been proposed as the actual reaction during chalcopyrite leaching in chloride system.

The change in the oxidation mechanism is likely the reason for the faster reduction on the $\mathrm{Fe}(\mathrm{III})$ concentration observed during leaching with $\mathrm{NaCl}$ in the present study. This can be inferred by comparing Figs. 2 and 3 . Although part of ferric iron is precipitated as natrojarosite, the concentration of ferrous iron is higher in the presence of $\mathrm{NaCl}$ than in its absence. This effect is higher for $1.0 \mathrm{~mol} / \mathrm{L} \mathrm{NaCl}$ and higher concentrations compared to the experiment carried out with $0.5 \mathrm{~mol} / \mathrm{L}$ $\mathrm{NaCl}$, matching the behaviour observed for copper dissolution (Fig. 1). The increase in Fe(II) concentration would be ascribed to the fast $\mathrm{Cu}(\mathrm{I})$ oxidation (Eq. (7)) instead of the direct mineral oxidation which is slow due to chalcopyrite passivation. The fast leaching kinetics observed with the $\mathrm{Cu}(\mathrm{II}) / \mathrm{Cu}$ (I) couple is attributed to a good overlap between the energy levels of the $\mathrm{Cu}(\mathrm{II}) / \mathrm{Cu}$ (I) couple and the conduction band of chalcopyrite while the energy levels of the $\mathrm{Fe}(\mathrm{III}) / \mathrm{Fe}$ (II) couple are within the chalcopyrite band gap, and the leaching kinetics is therefore slower (Venkatachalam, 1991).

\subsection{Effect of chloride ion on the surface properties of the reaction products}

Scanning electron micrographs (Fig. 5a-e) show that ferric sulphate leaching of chalcopyrite without $\mathrm{NaCl}$ produces an adherent reaction product that follows the morphology of the chalcopyrite grains. This new surface is roughened although an increase of surface area is not observed. Actually, surface area is reduced compared with that of the concentrate. This finding is consistent with other works regarding chalcopyrite oxidation (Elsherief, 2002; Majima et al., 1985).

Unlike the morphology of the reaction product generated in the absence of $\mathrm{NaCl}$ where "... chalcopyrite particle was completely coated by an amorphous or cryptocrystalline film of sulphur", Lu et al. (2000a) state that a crystalline and porous sulphur layer is formed in the presence of $\mathrm{NaCl}$. However, the authors made this statement only by analysis of SEM images. In the present work, however, it was possible to determine the surface area and porosity of leach residue in the presence and absence of $\mathrm{NaCl}$. Table 1 shows that there is a reduction of surface area and porosity after 


\section{(a)}

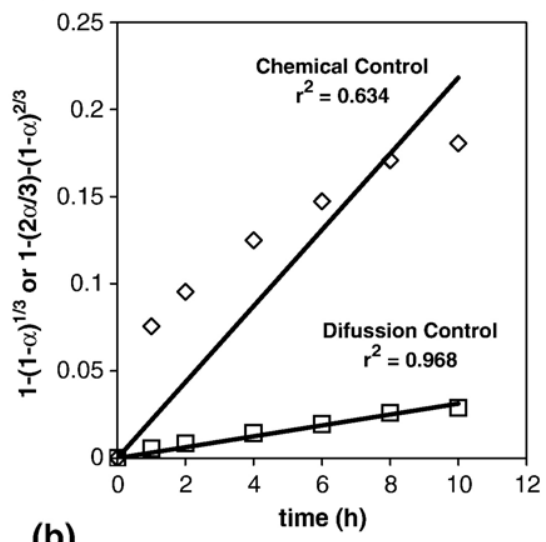

(b)

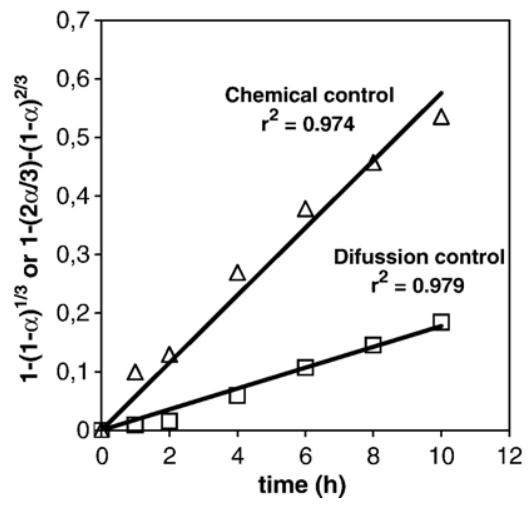

Fig. 6. Plot of leaching data according to the shrinking core model without (a) and with $1.0 \mathrm{~mol} / \mathrm{L} \mathrm{NaCl}$ (b). Conditions: T: $95{ }^{\circ} \mathrm{C}$, $d_{50}=5.5 \mu \mathrm{m}$.

leaching with ferric sulphate. As jarosite was not observed in these experiments, it is suggested that an elemental sulphur layer has grown, coating the surface and reducing those parameters. In the presence of $\mathrm{NaCl}$, however, the reduction in both surface area and porosity is less evident and the values approach those of the concentrate. Table 1 also confirms that in the presence of $\mathrm{NaCl}$, surface area and porosity of the leach residue are higher than those obtained without sodium chloride. Another evidence for these findings is present in Fig. 6, which depicts the shrinking core kinetic model for the extraction data presented in Fig. 1. The simplified equations of shrinking core model for either diffusion or surface reaction controlled process are, respectively (Levenspiel, 1999):

$\left[1-\frac{2}{3} \alpha-(1-\alpha)^{\frac{1}{3}}\right]=k_{\mathrm{D}} \cdot t$

$\left[1-(1-\alpha)^{\frac{1}{3}}\right]=k_{\mathrm{SR}} \cdot t$ where $\alpha$ is the fraction reacted; $t$ is time; $k_{\mathrm{SR}}$ and $k_{\mathrm{D}}$ are the apparent rate constant for either surface reaction or diffusion control, respectively.

It can been seen that in both conditions (with and without $\mathrm{NaCl}$ ) the diffusion controlled model fits better the leaching data than the chemical reaction model (Levenspiel, 1999) as observed by other authors (Gupta and Mukherjee, 1990; Mateos et al., 1987; Munoz et al., 1979). Nevertheless, when only the chemical reaction control is considered, it can be noticed that the experiments where sodium chloride was added show a better fit $\left(r^{2}=0.974\right)$ than those performed in its absence $\left(r^{2}=0.634\right)$; i.e. diffusion through the reaction products is slower in those experiments where $\mathrm{NaCl}$ was not present. Furthermore, in the presence of $\mathrm{NaCl}$ both equation fits (chemical reaction and diffusion controls) are similar suggesting that a change in reaction mechanism may be taking place.

The effects of chloride ions on chalcopyrite leaching can be summarized as follows: chloride ions affect the chemistry of leaching, enabling chalcopyrite dissolution by the $\mathrm{Cu}(\mathrm{I}) / \mathrm{Cu}$ (II) redox couple which shows large mixed potentials during leaching; and, as confirmed in the present work, changes the morphology of the reaction product thereby increasing copper extraction. The combination of both effects accounts for the faster leaching kinetics of chalcopyrite in the presence of chloride ions.

\section{Conclusions}

An oxygenated ferric sulphate-sodium chloride solution could be successfully applied to the leaching of a chalcopyrite concentrate under atmospheric pressure and $95{ }^{\circ} \mathrm{C}$. It has been shown that $\mathrm{NaCl}$ has a positive effect over chalcopyrite leaching with ferric sulphate. Copper extraction increased from $45 \%$ to $91 \%$ when $\mathrm{NaCl}$ is added to the reaction system. It was confirmed by surface area and porosity measurements that chloride ions affect the morphology of the reaction product formed producing a porous and somewhat crystalline sulphur layer. The change in porosity facilitates reagent diffusion through the reacting product layer improving the leaching kinetics.

\section{Acknowledgement}

This work was supported by "FINACIADORA DE ESTUDOS E PROJETOS-FINEP". The "Coordenação de Aperfeiçoamento de Pessoal Docente, CAPES, scholarship to M.F.C. Carneiro and the support of Companhia Vale do Rio Doce (CVRD) are gratefully acknowledged. 


\section{References}

Amer, A.M., 1995. Investigation of the direct hydrometallurgical processing of mechanically activated complex sulphide ore, Akarem area, Egypt. Hydrometallurgy 38, 225-234.

Baláz, P., Kupka, D., Bastl, Z., Achimovicová, M., 1996. Combined chemical and bacterial leaching of ultrafine ground chalcopyrite. Hydrometallurgy 42, 237-244.

Boekema, C., et al., 2004. $\mathrm{Cu}$ and Fe valence states in $\mathrm{CuFeS}_{2}$. Journal of Magnetism and Magnetic Materials 272-276, 559-561.

Carneiro, M.F.C., Leão, V.A., 2005. Lixiviação da calcopirita com cloreto férrico e cloreto de sódio. Revista Escola de Minas 58 (3), 231-235.

Defreyne, J., Barr, G., McCunn, G., Costa, R.S., Gonçalves, L.R.L., 2004. CESL copper process-moving form pilot plant to production scale operation. In: Vargas, T. (Ed.), Hydro-Sulfides. Universidad de Chile, Santiago do Chile, Chile, pp. 370-382.

Dreisinger, D.B., 2004. New developments in the hydrometallurgical treatment of copper concentrates. In: Vargas, T. (Ed.), Hydro-Sulfides. Universidad de Chile, Santiago do Chile, Chile, pp. $47-73$.

Dutrizac, J.E., 1992. The leaching of sulphide minerals in chloride media. Hydrometallurgy 29, 1-45.

Elsherief, A.E., 2002. The influence of cathodic reduction, $\mathrm{Fe}(\mathrm{II})$ and $\mathrm{Cu}(\mathrm{II})$ ions on the electrochemical dissolution of chalcopyrite in acidic solution. Minerals Engineering 15, 215-223.

Filfield, F.W., Kealey, D., 1995. Analytical Chemistry. Champman \& Hall, London. 560 pp

Gupta, C.K., Mukherjee, T.K., 1990. Hydrometallurgy in Extraction Processes, vol. 1. CRC Press, Boca Raton. 225 pp.

Hackl, R.P., Dreisinger, D.B., Peters, E., King, J.A., 1995. Passivation of chalcopyrite during oxidative leaching in sulfate media. Hydrometallurgy 39, 25-48.

Haver, F.P., Wong, M.M., 1971. Recovery of copper, iron and sulfur from chalcopyrite concentrate using a ferric chloride leach. Journal of Metals 25-29.

Havlik, T., Kammel, R., 1995. Leaching of chalcopyrite with acidified ferric-chloride and carbon-tetrachloride addition. Minerals Engineering 8 (10), 1125-1134.

Hirato, T., Kinoshita, M., Awakura, Y., Majima, H., 1986. The leaching of chalcopyrite with ferric chloride. Metallurgical Transactions. B, Process Metallurgy 17, 19-28.

Hirato, T., Majima, H., Awakura, Y., 1987. The leaching of chalcopyrite with cupric chloride. Metallurgical Transactions. B, Process Metallurgy 18 (1), 31-39.

Jones, D.L., Peters, E., 1976. The leaching of chalcopyrite with ferric sulfate and ferric chloride. In: Jones, D.L., Peters, E. (Eds.), Extractive Metallurgy of Copper. Aime, New York, pp. 633-654.

Lazaro, I., Nicol, M., 2003. The mechanism of the dissolution and passivation of chalcopyrite: an electrochemical study. In: Young, C.A., et al. (Ed.), Hydrometallurgy. TMS, Vancouver, Canada, pp. $405-416$.

Levenspiel, O., 1999. Chemical Reaction Engineering. John Wiley \& Sons, New York. 664 pp.

Lu, Z.Y., Jeffrey, M.I., Lawson, F., 2000a. The effect of chloride ions on the dissolution of chalcopyrite in acidic solutions. Hydrometallurgy 56, 189-202.
Lu, Z.Y., Jeffrey, M.I., Lawson, F., 2000b. An electrochemical study of the effect of chloride ion on the dissolution of chalcopyrite in acid solutions. Hydrometallurgy 56, 145-155.

Lu, Z.Y., Jeffrey, M.I., Zhu, Y., Lawson, F., 2000c. Studies of pentlandite leaching in mixed oxygenated acidic chloride-sulfate solutions. Hydrometallurgy 56, 63-74.

Majima, H., Awakura, Y., Hirato, T., Tanaka, T., 1985. The leaching of chalcopyrite in ferric chloride and ferric sulfate solutions. Canadian Metallurgical Quarterly 24 (4), 283-291.

Martell, A.E., Smith, R.M., 2003. NIST Critically Selected Stability Constants of Metals Complexes. National Institute of Standards and Technology, Gaithersburg, MD.

Mateos, F.B., Pérez, I.P., Mora, F.C., 1987. The passivation of chalcopyrite subjected to ferric sulfate leaching and its reactivation with metal sulfides. Hydrometallurgy 19, 159-167.

Maurice, D., Hawk, J.A., 1998. Ferric chloride leaching of mechanically activated chalcopyrite. Hydrometallurgy 49 (1-2), 103-123.

Mikhlin, Y.L., et al., 2004. Spectroscopic and electrochemical characterization of the surface layers of chalcopyrite $\left(\mathrm{CuFeS}_{2}\right)$ reacted in acidic solutions. Applied Surface Science 225, 395-409.

Munoz, P.B., Miller, J.D., Wadsworth, M.E., 1979. Reaction mechanism for the acid ferric sulfate leaching of chalcopyrite. Metallurgical Transactions. B, Process Metallurgy 10, 149-158.

Nicol, M.J., Needes, C.R.S., Finkelstein, N.P., 1975. Electrochemical model for the leaching of uranium dioxide: 1. Acid media. In: Burkin, A.R. (Ed.), Leaching and Reduction in Metallurgy. The Institution of Mining and Metallurgy, London.

O'Malley, M.L., Liddell, K.C., 1987. Leaching of $\mathrm{CuFeS}_{2}$ by aqueous $\mathrm{FeCl}_{3}, \mathrm{HCl}$ and $\mathrm{NaCl}$ : effects of solution composition and limited oxidant. Metallurgical Transactions. B, Process Metallurgy 18, 505-510.

Peacey, J., Guo, X.J., Robles, E., 2005. Copper HydrometallurgyCurrent Status, Preliminary Economics, Future Direction and Positioning Versus Smelting. Hatch Associates Ltd, Mississauga, Ontario, p. 18.

Pearce, C.I., Pattrick, R.A.D., Vaughan, D.J., Henderson, C.M.B., van der Laan, G., 2006. Copper oxidation state in chalcopyrite: mixed $\mathrm{Cu} d(9)$ and $d(10)$ characteristics. Geochimica et Cosmochimica Acta 70 (18), 4635-4642.

Prasad, S., Pandey, B.D., 1988. Alternative processes for treatment of chalcopyrite - a review. Minerals Engineering 11 (8), 763-781.

Rouquerol, F.R., Sing, K., 1999. Adsorption by Powders \& Porous Solids-Principles, Methodology and Applications. Academic Press, New York. 467 pp.

Skorobian, M., Havlik, T., Ukasik, M., 2005. Effect of $\mathrm{NaCl}$ concentration and particle size on chalcopyrite leaching in cupric chloride solution. Hydrometallurgy 77, 109-114.

Venkatachalam, S., 1991. Treatment of chalcopyrite concentrates by hydrometallurgical techniques. Minerals Engineering 4, 1115-1126.

Warren, G.W., Wadsworth, M.E., El-Raghy, S.M., 1992. Passive and transpassive anodic behavior of chalcopyrite in acid solutions. Metallurgical Transactions. B, Process Metallurgy 13, 571-579.

Winand, R., 1991. Chloride hydrometallurgy. Hydrometallurgy 27, 285-316.

Yamakawa, K., Hine, F., 1970. Mechanism of oxidation of cuprous ion in hydrochloric acid solution by oxygen. Electrochimica Acta 15 (4), 769-781. 